\title{
Z Kuşağı Çalışma Alanları: Değişen Ofis Kavramının Tasarımda Mekan Kurgusuna Etkisi
}

\author{
Melisa UNVAN ${ }^{1 *}$, Özgü ÖZTURAN ${ }^{1}$
}

\begin{abstract}
Öz
Bireylerin doğduğu yıllara göre parçası oldukları jenerasyonlar, kişilik özelliklerini, bakış açılarını, beklentilerini büyük ölçüde etkilemektedir. Yaşamın her alanında olduğu gibi iş hayatı ve çalışma ortamı, bireyi bedensel ve zihinsel olarak derinlemesine etkileyen etmenlerdir. İnsanoğlunun yaşamının neredeyse yarısını çalışarak geçiren bir canlı olduğu düşünülürse, çalışma mekanlarının hayatın yönelimine etkisi yadsınamayacak düzeydedir. Çalışma mekanlarının anlamının yeniden sorgulandığı bu dönemde yeniden kurgulanması düşünülen iş ortamının mekana etkileri de güncel tartışma konusu haline gelmiştir. Çalışma mekanının performansa etkisi düşünüldüğünde iş hayatına önümüzdeki yıllarda atılacak olan, bugünün gençleri $Z$ kuşağı bireylerinin de çalışmayı tercih ettiği mekanların incelenmesi konusu önem arz etmektedir. Çalışma alışkanlıkları kendilerinden önceki kuşaklarla göz ardı edilemeyecek farklııklar göstermekte olan bu kuşağın intiyaçlarının belirlenmesi bu bağlamda gelecek yılların önemli bir intiyacı olmaktadır olacaktır. Bu çalışmanın amacı; $Z$ kuşağı için ideal ofis tasarımının intiyaçlarını belirlemek $Z$ kuşağının beraber çalışacağı $X$ ve $Y$ kuşaklarının çalışma ortamları ile beraber değerlendirilmesi bağlamında yapılan literatür araştırmaları ile birlikte örnek incelemelerle desteklemek ve ideal ofis tasarımı önerilerinde bulunmaktır.
\end{abstract}

Anahtar kelimeler: Z kuşağı, ofis tasarımı, geçirgenlik, özgürlük, teknolojik mekân.

\section{Generation Z Working Areas: the Effect of Changing Office Concept on Space Setup in Design}

\begin{abstract}
The generations that individuals are a part of, according to the years they were born, greatly affect their personality traits, perspectives and expectations. As in all areas of life, business life and working environment are the factors that change the individual physically and mentally. Considering that a person spends most of his life by working, the effect of working spaces to life is undeniable. Since the meaning of working spaces is being questioned again, the effects of the work environment, which is thought to be reconstructed, on the space have also become a current topic of discussion. Considering the effect of the place on the performance, it is important to examine the places where generation $Z$ individuals also prefer to work. In this context, determining the needs of this generation, whose working habits show differences that cannot be ignored, is a necessity of the period. The aim of this study is; It is to support the needs of the ideal office design for the $Z$ generation with the literature researches conducted in the context of evaluating the working environments of the $X$ and $Y$ generations with which the $Z$ generation will work together, and to suggest ideal office design.
\end{abstract}

Keywords: Generation Z, office design, permeability, freedom, technological space.

\footnotetext{
${ }^{1}$ Akdeniz Üniversitesi, Fen Bilimleri Fakültesi, Antalya Türkiye

* İlgili yazar/Corresponding author: gamze. melisaunvan@gmail.com

Gönderim Tarihi: 14.10.2020

Kabul Tarihi: 11.12.2020
} 


\section{GiRiş}

İnsanoğlu varoluşundan bu yana çalışma kavramıyla iç içedir. Ancak çağlar boyu bu kavramın günlük yaşamda sahip olduğu yüzdelik dilim giderek artmış ve 20. yüzyıldan itibaren çalışma hayatı günün oldukça büyük bir kısmını kaplar olmuştur. Artan bu oran tasarımcıların da dikkatini çekmiş ve uzun süreli etkileşimde olduğumuz çalışma mekânlarının bireyin psikolojisine, üretkenliğine ve devamlılı̆ına etkileri gibi konular araştırılmaya başlanmıştır. Yeni üretilen çalışma mekanları bu araştırmalara göre tasarlanırken, büyük şirketler de dönemin yeni kaygısını göz ardı etmemiş ve intiyaca yönelik düzenlemeler yapılmıştır.

20. yüzyıl, dönem dinamiğinin çok hızlı ve çeşitli değişiklik gösterdiği bir çağ olmuştur. $\mathrm{Bu}$ nedenledir ki insan psikolojisi de bu tempoya ayak uydurur nitelikte sık aralıklarla değişim sergilemiş ve bu aralıkların sınıflandırılması gerekliliği doğurmuştur. Kuşak kavramı da bu intiyaçtan doğarak; aynı dönemde doğmuş, büyümüş ve hayatını sürdürmüş olan ve dolayısıyla benzer olaylara benzer yaklaşımları gösteren bireylerin oluşturduğu zaman aralığı olarak tanımlanmıştır (Berkup, 2014, s. 219). Kuşaklar birçok alanda ortak bakış açılarına, benzer çözüm yöntemlerine ve birbirini tamamlayan beklentilere sahiplerdir. Şu ana kadar tanımlanmış olan kuşaklar: Gelenekselciler (1900-1927), Sessiz kuşak (1927-1945) ve Babyboomer (1946-1964) kuşakları ile birlikte X (1965-1980), Y (1981-1999) ve Z (2000-) kuşaklarıdır (Çetin ve Karalar, 2016, s. 159). Kısa sayılabilecek zaman aralıklarında değişiklik gösteren kuşakların çalışma mekânlarının da kullanıcıların intiyaç ve isteklerine göre düzenlenmesi gerekliliğini doğurmuş ve tasarımcılar bu yeni alanla ilgili çalışmalara başlamıştır.

Geçtiğimiz yıllarda büyük ölçekli firmaların yoğunlukla üzerinde durduğu konu haline gelen ideal ofis tasarımları özellikle Z kuşağının çalışma hayatına girecek olmasıyla tekrar yoğunlukla çalışılan bir konu haline gelmiştir. 21. yüzyılda, çağın dinamikliğinin birçok alanda olduğu gibi çalışma mekanları tasarımlarında da etkisi olması kaçınılmazdır. Önceki çağın bölmeli ofis mekanları ile birlikte ardından gelen ve henüz yeni alışılmış açık planlı ofis tasarımlarının, yeni yüzyılla birlikte doğduğu andan itibaren yoğun teknolojiyle büyüyen milenyum neslinin, alışılmamış karakteristik özellikleri ile birlikte köklü değişimlere uğraması beklenmektedir.

İş hayatına yeni atılan $Z$ kuşağı için ideal ofis mekanlarını anlamak ve tanımlamak amacıyla yapılan bu çalışmada öncelikle kuşak kavramı ile birlikte $Z$ kuşağının çalışma arkadaşları olacak olan $X$ ve $Y$ kuşaklarının genel özellikleri incelenmiş, ofis kavramının ve gerekliliklerinin değişimi kuşaklar kapsamında araştırıımış ve $Z$ kuşağı için ideal ofis mekanlarına çağ ötesi öneriler yapılmıştır.

\section{KUŞAK KAVRAMI X, Y VE Z KUŞAKLARININ GENEL ÖZELLİKLERİ}

Tarih boyunca dünya üzerine talepleri neredeyse sabit bir izde devam etmiş ve düşük hızda değişim göstermiş olan insanoğlunun, etkileşim halinde olduğu bilgilerin artması nedeniyle beklentilerinin de çeşitlenmesi beklenilen bir tepkidir. Değişim kavramının etkisi ve hızının günden güne artması, insanlığın karakter değişime doğrudan yansımış ve iletişimi günden güne zorlaştırmıştır. Biyolojik olarak 'ebeveynlerin doğum yılı ile çocuklarının bir sonraki nesli oluşturmaya başladıkları yıllar arasında kalan dönem' bir jenerasyon olarak tanımlanırken, bu tanım hızla gelişen teknoloji etkisindeki kültür değişim hızının artışı nedeniyle gitgide daralmış ve biyolojik sınırlar yerine nesillerin sosyal bakış açılarına göre sınıflandırılmaların yapılıyor olması durumu söz konusu olmuştur (McCrindle, 2014, s. XII). Kuşaklar öncelikle Auguste Comte tarafından belirli zaman aralıklarında değişim gösteren kuvvetler olarak tanımlanmış (1974), sonrasında 
Karl Mannheim ortak değerleri ve alışkanlıkları paylaşan dönemler olarak tanımlamış (1998) ve Claude Lagree bu kavramdan dünyayı paylaşan ve tanık oldukları olaylar ortak olan toplulukları nesil olarak bahsetmiştir (Taş vd., 2017, s.1034). Birbirleriyle paylaştıkları günden güne artan nesiller, çalışma ortamlarını da paylaşmaya başlamış ve her gelen nesil kendinden öncekileri şaşırtan değişimler gösterir olmuştur.

Birbirini kısa periyotlarla takip eden $X, Y$ ve $Z$ kuşaklarının günlük yaşamlarında oldukça fazla ortak davranışlar sergilemeleri beklenir. İnsanın doğası gereği kuşaklar arası anlaşmazlıklar her ne kadar tolere edilse de bazen küçük nüanslarla bazense hatırı sayılır ölçüde vuku bulan farklılıklar da yadsınamayacak değerdedir.

İçine doğdukları savaş dünyası ve savaş sonrası dönemin devletlerarası rekabete dayanarak hızlı gelişime olan açlığı ve yatkınlığı düşünüldüğünde, bu dönemde doğan $X$ kuşağı bireylerinin değişime yatkın olmaları beklenen bir sonuç olacaktır. İlk kişisel bilgisayarlarını kullanan dönem olan X kuşağının teknolojiye olan yatkınlığının sebebi de içinde bulundukları hızla gelişen ortamdan kaynaklanmaktadır (Adıgüzel vd., 2014, s.172). Değişim hızı bu denli olan bir ortamda yetişen bireylerin adaptasyon kabiliyetlerinin de doğru orantılı olarak gelişmiş olması olağandır. Bu kuşakta doğan bireyler kendi kendine yetmeye uğraştıkları için: çözüm odaklı, öğrenmeye açık, çalışmaktan gocunmayan, işini azimle yapan, topluma karşı duyarlı bireylerdir (Akdemir vd., 2013, s. 15). İçine doğdukları mücadeleci toplum bireylerin farklı olma isteğini kamçılamış ve $X$ kuşağının kendinden önce gelen sakin kuşakla bazı anlaşmazlıklar yaşamasını kaçınılmaz kılmıştır. Ebeveynlerine kıyasla daha eğitimli olan bu dönem bireyleri, kişisel gelişimlerine verdikleri önemle de sessiz kuşaktan ayrılmaktadırlar (Çetin ve Karalar, 2016, s.159). Karakter özellikleri doğrultusunda çalışma hayatında da bireysel çalışmaları ekip işlerine kıyasla daha çok tercih eden kuşak, mekânlarının da ayrıştırımasına ve hiyerarşinin de bu ayrımla anlatılmasına yatkındır.

Çalışmak kavramıyla özdeşleşmiş olan $X$ kuşağı bireylerinin küçük kardeşleri olarak nitelendirilebilecek olan $Y$ kuşağının karakter oluşumunda $X$ kuşağının özellikleri önemli bir etken olmuştur. Doğdukları dünyanın özellikleri düşünüldüğünde: iletişimin hızla arttığı, mesafelerin hızla kısaldığı, dünyanın ortak bir kültürü oluşturmaya başladığı Y kuşağının özgür ruhlara sahip olan bireylerden oluştuğu tahmin edilebilir. Dünyanın ilk teknolojik ve küresel jenerasyonu olan bu kuşak, aşırı planlanmış ve her bireyin bir uğraşının olduğu bir dünyaya doğmuş olmalarından kaynaklı olarak son derece eğitimli bireylerden oluşmaktadır (Berkup, 2014, s.122). İlk andan itibaren küreselleşmiş bir dünyayı tanıyan bu kuşak bireyleri; farklı kültürlere, etnik kökenlere, cinsiyet ve ırklara, diğer kuşaklara kıyasla daha saygılıdır. Kendilerindeki bu farkı keşfeden $Y$ kuşağı, hem sosyal hem de iş hayatında fark yaratması muhtemel neslin kendileri olduğunu öngörmektelerdir (Akdemir vd., 2013, s.18). Hayatlarının her alanında hız bulunan bu nesil, sabırsız tavırlara sahiplerdir. Bu özellikleri iş hayatında da verilen işi hızla ve titizlikle tamamlamak, sağlanan bilgiyi çabuk özümsemek ve öğrenmek, dünyayla iletişim halinde olmak gibi pozitif özelliklerinin yanı sıra; sürekli geri bildiri almayı beklemek, hızı mertebe kazanmayı istemek, iş yerine sadakatin ve bağlıı̆ıı az olması gibi negatif sayılabilecek etkileri de doğurmuştur (Adıgüzel vd., 2014, s.173,174).Çalışma prensiplerinde esnek saatlerde ve tercihen esnek mekanlarda çalışmayı tercih etmelerinin yanı sıra; iletişim çağına doğmalarından kaynaklı olarak takım çalışmasına eğilimleri de oldukça fazladır (Akdemir vd., 2013, s.15). Aşina oldukları teknoloji sayesinde sınırsız bilgiye ulaşabilen bu neslin öğrenmeye olan isteği, kendini geliştirmeye olan azmi düşünüldüğünde; başarının verdiği tatmin duygusu ve mertebedeki yükselmenin bu neslin bireyleri için önem arz ettiğini söylemek mümkündür. 
Dijital bir dünyaya doğmuş olan Z kuşağının hayatında yer alan kavramlar kendinden önce gelen kuşaklardan, özellikle ebeveynleri olan $X$ kuşağıyla, büyük farklılıklar göstermektedir. Son derece hızlı bir ilerleyiş gösteren dijital çağ, toplum üzerinde büyük etkiler yaratan sosyal medya uygulamalı iler birlikte bu yeni nesli kendine bağımlı hale getirmekte ve karakterleri üzerinde oldukça büyük tesir sağlamaktadır (Berkup, 2014, s.224). İçine doğdukları internet çağını kendinden önce gelen nesiller gibi bir yenilik olarak değil, günlük yaşamlarının bir parçası olarak görüyor olmaları nedeniyle; teknolojiyi kullanırken de önceki nesiller kadar dikkatli olmadıklarından dolayı hızla yayılan bilgi kirliliği gibi problemlerle de başa çıkmaları gerektiği öngörülebilmektedir. Diğer kuşaklara kıyasla daha hırslı olan Z kuşağına mensup olanlar, bilgiye erişim kolaylıkları kaynaklı materyalist düşünce yapısına sahip ve dolaylı olarak ikili ilişkilerde problem yaşayan bireylerdir (Kırık ve Köyüstü., 2018, s.1504). Bunun sebebi de bu nesil bireylerinin sanal dünyaya alışkın ve yatkın oluşlarından kaynaklı yalnız olmaya meyillerinin oluşu ve yüz yüze iletişimdense sanal ortamda gerçekleştirilen iletişimlerde kendilerini daha rahat hissetmeleridir. İş hayatına yeni atılmakta olan bu neslin istekleri kesin olmamakla birlikte; sanal dünyaya ve bireyselliğe olan yatkınlıkları nedeniyle gerek iş hayatından gerekse çalışma ortamlarından da beklentilerinin istediklerinde yalnız kalabilecekleri ve genellikle iletişimin dijital ortamda gerçekleştiği çok fonksiyonlu yapıya sahip olunması olacağı tahmin edilebilmektedir. İstedikleri bilgiye istedikleri her an ulaşabilen $Z$ kuşağı, hayatlarının her alanında aynı performansı beklemeleri nedeniyle sabırsız bir tavır sergilerler. Bu nedenle $Z$ kuşağı tatminsiz, kararsız ve doğuştan tüketici olarak tanımlanırken aynı zamanda, adaleti ve barış iklimini savundukları, dürüstlüğe önem verdikleri, kendilerini ifade etmekte oldukça rahat oldukları ve girişimcilik yönlerinin ağır bastığı söylenmektedir (Taş vd., 2017, s.1037). Küresel kültürün oluştuğu, farklı dilden, dinden, ırktan, görüşten insanların ortak ancak sanal paylaşımlarının olduğu bir dünyayı tanıyan $Z$ kuşağı, iş hayatında da benzer beklentilere sahiptir. Çeşitli sektörlerden firma yöneticileri, çalışma hayatına yeni giren bu kuşakla birlikte çalışma planlarının tamamen değişeceği, esnek çalışma saat ve ortamlarının gerekeceği, sabit departmanlar yerine değişken proje gruplarının oluşacağı, fiziksel olarak birlikte olmanın artık bir intiyaç olmayacağı ve uluslararası takım üyeleriyle birlikte çalışılan grupların kurulacağı şeklinde çıkarımlar yapmaktadır (Taş vd., 2017, s.1041). Bu sebeple çalışma ortamlarının da gelmekte olan Z kuşağına göre yeniden düşünülmesi intiyacı dünyanın önde gelen firmaları tarafından gündeme alınmıştır.

\section{KUŞAKLAR İLE DEĞIŞEN OFIS KAVRAMI}

Toplumlar geliştikçe onunla birlikte gelişen faaliyet alanları ile üretilen yeni iş tanımları beraberinde daha önce karşılaşılmamış intiyaçları da getirmişlerdir. Geçtiğimiz yüzyılda değişim hızı parabolik olarak artan ofis kavramı, dijital sistemlerin hayatımıza büyük oranda girmesi ve internet çağının başlamasıyla alışılanın dışında taleplerle gündeme gelmeye başlamıştır. Bu nedenle günümüzde üç kuşağa birden hizmet edecek ofis ortamlarının, bireylerin çalışma performansı da düşünülerek yeniden düzenlenmesi intiyacı tasarımcılar tarafından üzerinde durulan bir konu olmuştur. 


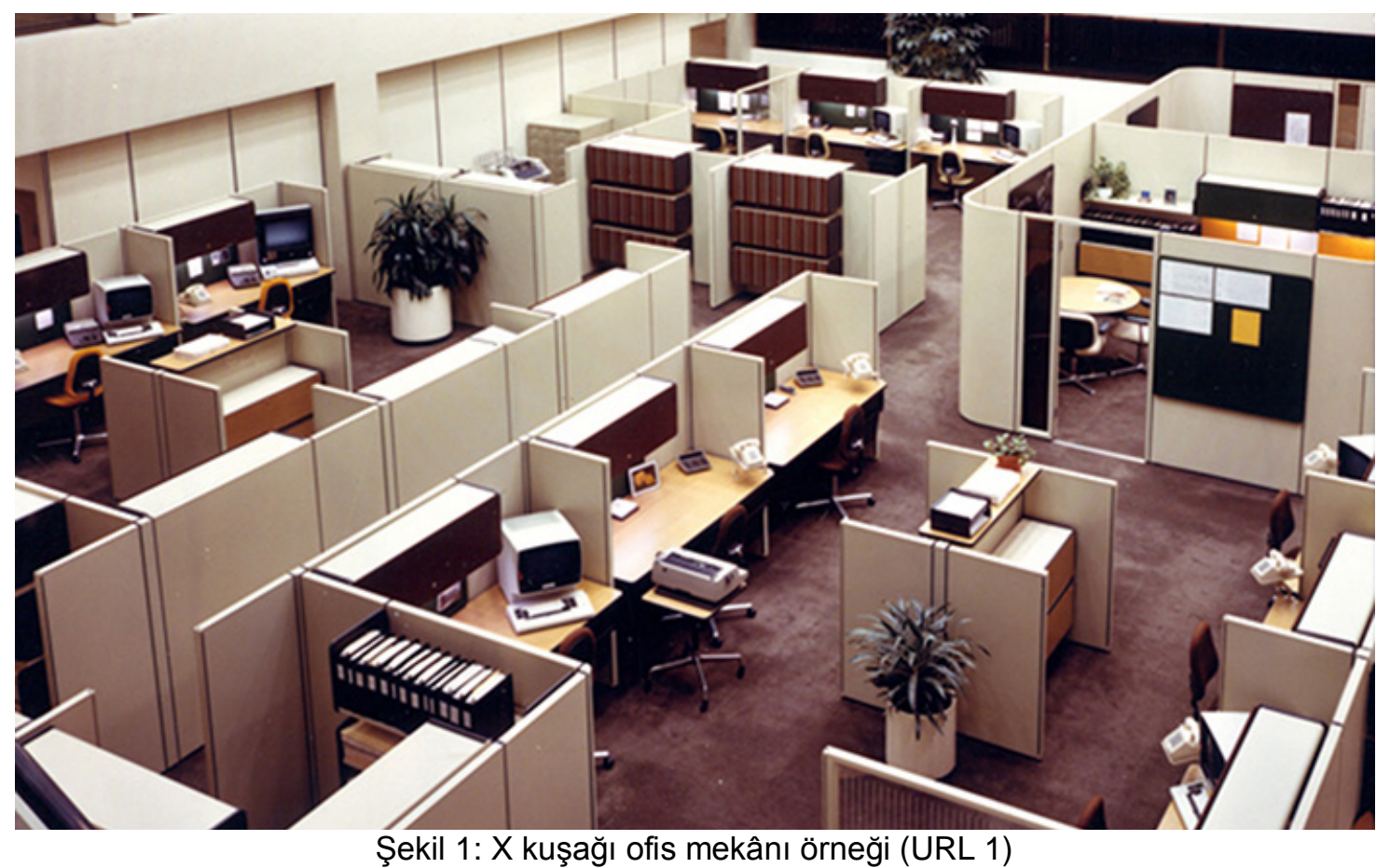

Atlatılan savaşın etkilerinin sürmekte olduğu bir dönemin ebeveynleri tarafından yetiştirilmiş olan $X$ kuşağı bireyleri; kendi işlerini kendileri yapmaya alışmış ve düzenli çalışma ahlakı oturmuş bireyler olarak açıklanmışlardır. Söz konusu kuşağın çalışma hayatından beklentileri de kendinden sonra gelen nesillere kıyasla daha düşüktür. Kurumsal firmaların oluşmakta olduğu yıllarda çalışma hayatına atılan bu neslin çalışma hayatından; esnek çalışma saatlerine sahip olmak, uygun süreçte ve sergilenen yetenekte terfi almak, tatmin edici bir ofis ortamına sahip olmak gibi beklentilerinin olduğu bilinmektedir (Berkup, 2014, s.221). Birçok birimden oluşan firmalarda hiyerarşik sistemlerin kurulma intiyacından dolayı sabit dizilimlere sahip olması ve çok bölmeli ofislerin bu dönemin özelliklerinden olması beklenen bir sonuçtur (Şekil 1). 1950 ve 1970 yılları arasında en yüksek popülasyona ulaşan açık bölmeli ofis tasarımlarının asıl amacı, gerektiğinde hiyerarşik düzendeki değişime adapte edilebilecek organik birimler oluşturmak olarak bahsedilmiştir (Brennan et al., 2002). İşletmeler ve yöneticilerinin ofis tasarımına yaklaşımları; duvar, halı mobilya gibi sabit elemanların renklerini değiştirmek ya da yeni tablolar asmak gibi düşük bütçeli çözümler üretmekken; asıl önem verdikleri çalışan ve yönetici birimlerini yetkileri ile orantılı olarak düzenlemek olmuştur (Stallworth and Kleiner, 1996). Ancak bu yaklaşım da neslin son döneminde değişim göstermiş ve açık planlı ofislere geçilmeye başlanmıştır. 


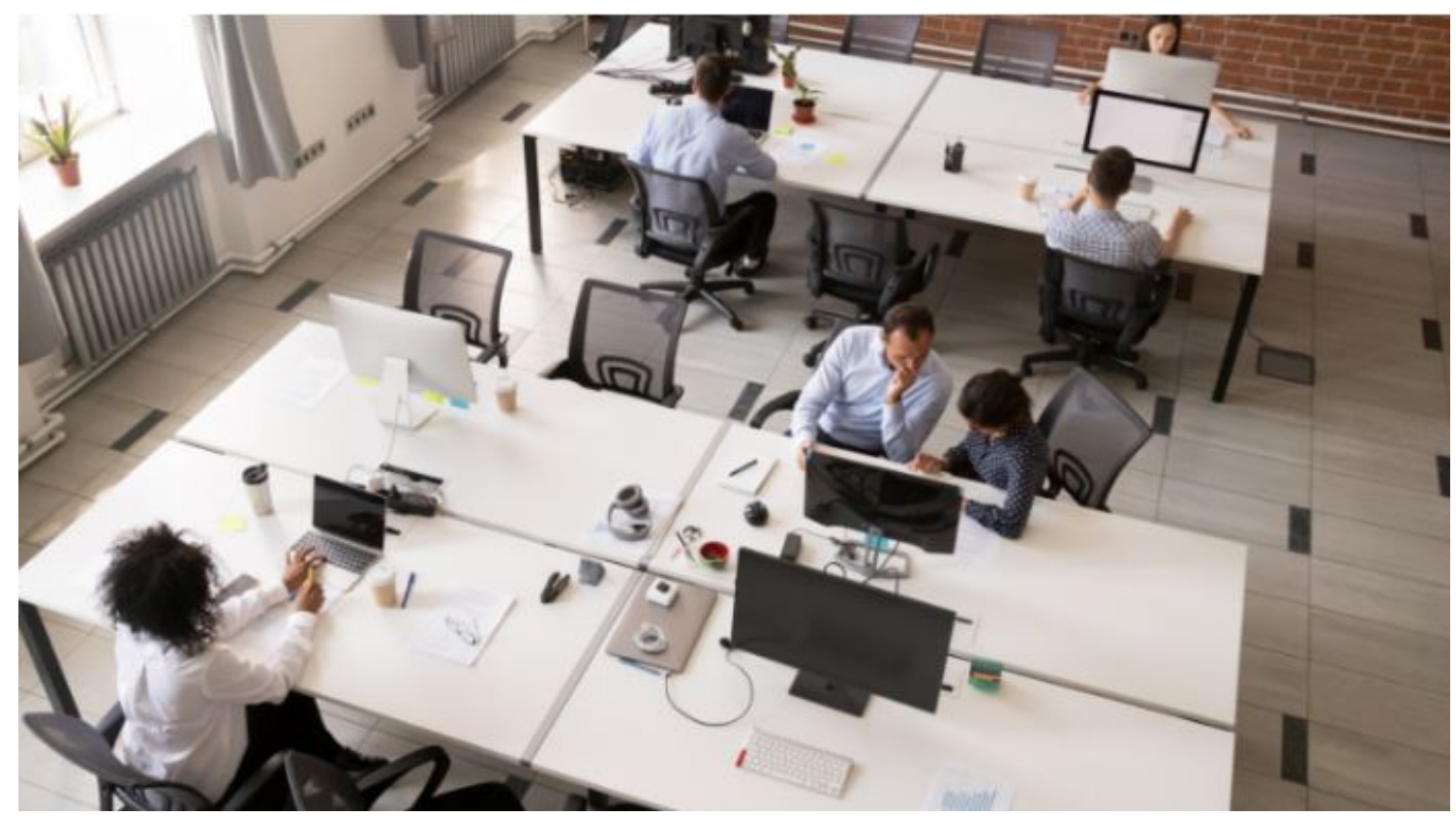

Şekil 2: Açık planlı ofis çözümleri (URL 2)

Sahip olduğu özgür ruh ve iletişime olan yatkınlığı düşünüldüğünde, Y kuşağının iş hayatına girmesiyle, $X$ kuşağı döneminden kalma sabit ayrımları olan ofis tasarımlarındaki değişim kaçınılmazdır. Teknolojik imkânların bir anda artış gösterdiği, iletişimin küresel boyuta ulaştığı bu dönemde çalışma şartlarında da bu dinamik ortama göre yeniden düzenlenme ihtiyacı duyulmuş ve çalışanlar arasında iletişimin ve eşitlik anlayışının artması istemiyle açık planlı ofisler tasarlanmıştır (Şekil 2). İletişim araçlarını aktif olarak kullanmayı isteyen nesil sabit bir çalışma ortamındansa kafelerde, kütüphanede, arkadaşlarının ofislerinde ya da evlerinde çalışmayı tercih ediyor olmalarından dolayı 'mobil çalışanlar' olarak tanımlanmışlardır (Adıgüzel vd.,2014, s.177). Çalışma ortamında farklılık isteyen neslin ihtiyacını karşılamak adına bu dönemde ofis tasarımlarında çalışanların ilgilerini aktif tutmaya ve motivasyonlarını arttırmaya yönelik değişimlere gitmişlerdir. Bireysel işlere yatkın olan Y kuşağı takım çalışmalarında aktif rol alabilmeleri için ofislerde ortak çalışma alanları düzenlenmiş ve istekleri doğrultusunda gerekli donanım ve ses, ışık, sıcaklık gibi konularda uygun ortam oluşturulmasına öncelik verilmiştir (Bosuncken and Reuschl, 2016). Açık planlı, herkesin eşit haklara sahip olduğu ofis düzenlemelerinde çalışanların şahsi masaları da değişen dinamizme ayak uydurmuş ve mobil çalışma anlayışı bireyselleşmiş mekanları da dönüştürmüştür. Çalışanların bilgisayar, tablet gibi iş hayatını içinde barındırdığı şahsi eşyalarıyla oturdukları yeri prize bağlandıkları andan itibaren kişiselleştiren 'takçıkar ofis' mantığı bu dönemde kullanılmaya başlanmıştır (Arabacıoğlu ve Arabacıoğlu, 2011). Çalışanın iş alanını intiyaçları doğrultusunda kendi kendine üretebildiği ya da keyfi doğrultusunda değiş̧irebildiği bir ofis tanımı da böylelikle yapılmış olmuştur.

Ofis kavramının değişimi $Y$ kuşağında $X$ kuşağına kıyasla daha hızı ve büyük ölçekli olarak gerçekleşmiştir. Bu değişimin Z kuşağında şimdiye kadar olanların hepsinden daha hızlı olduğu izlenmekte olup daha büyük çapta değişimlere ulaşacağı öngörülebilmektedir.

\section{Z KUŞAĞI OFIS TASARIMI}

Bu çağda hızla değişen dünyada, bireylerin çalışma mekanlarından beklentileri de yadsınamayacak oranda değişimler göstermektedir. Gittikçe birbirinden uzaklaşan insanoğlunun günümüzde geldiği noktada iş yerlerinde bireyselliğe verilen önemin de 
şimdiye dek deneyimlenmiş en üst seviyede olduğu görülmektedir. Yapılan bir çalışmada, işyeri kültürü olarak adlandırılan kavramsal başlık altında; her 3 aileden 1 'inin dağıldığı gözlemlenen bir çağda yaşayanların aileden gördüğü desteğin azalması, bireylerin yaşıtlarıyla iletişim kurma isteğinin artmasına ve ihtiyaç duyduğu ait olma ortamını işyerinde arama eğilimine sahip bireylerin birbiri ile olan ilişkileri incelenmiştir. Çalışmada Z kuşağı bireylerinin bireyselliğe itilmelerine sebep olan bu boşluğu, kendilerini anlayan işyerinden ziyade iş dışından meslektaşlarıyla doldurma isteği olduğu belirtilmektedir (McCrindle, 2014, s.17). Bu nedenledir ki kuşak bireyleri sosyal açıdan oldukça aktif bireyler olup iş yerlerinde geçirdikleri vakitleri minimumda tutma eğilimdedirler ve hatta genellikle farklı mekanlarda çalışma isteklerine sahiplerdir. Ofis mekanları bu isteğe yönelik olarak tekrar düşünülmekte ve lider firmalar, çalışanlarının intiyaçları doğrultusunda tasarımlar üretmek için efor sarf etmektedir. Çalışanların kendilerini evlerinde hissedecekleri sıcak koşullar, sosyalleşebilecekleri ortak mekânlar ve eğlenebilecekleri fonksiyonlara sahip ortamlar; çalışanların grup çalışmalarında daha aktif olabildiği ve farklılıktan doğan fikirlerin zenginliğinin desteklendiği iş hayatları hedeflenmektedir (Taş vd, 2017, s.1041). Bu amaçla; esnek planlara sahip olmak, aidiyet hissini kuvvetlendirmek adına ev mobilyalarıyla sıcak köşeler oluşturmak, hem sosyalleşmenin mümkün olduğu paylaşımlı kullanım hem de yalnızlığa erişilebilen bireysel mekanların olduğu ofisler yetişen yeni kuşak için tasarlanmaktadır (Şekil 3).

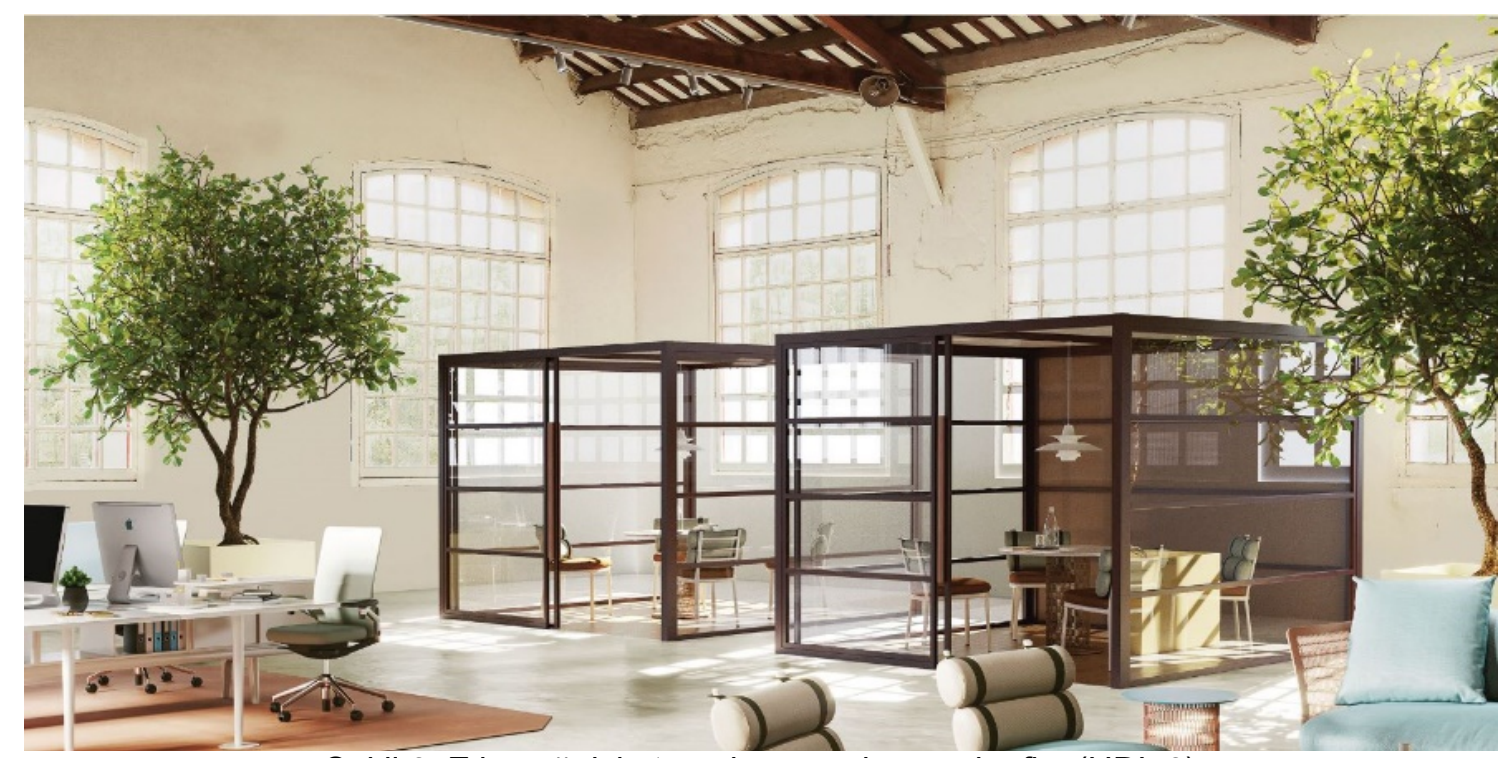

Şekil 3: Z kuşağı için tasarlanan çok parçalı ofis (URL 3)

Söz konusu neslin ofis ortamlarında aradıkları özelliklerden bir diğeri de dünya vatandaşı olma hislerini destekleyen sürdürülebilirliğe önem vermeleri durumundan kaynaklanan, daha çok doğal havalandırmanın kullanıldığı, bitki popülasyonun çok olduğu ve enerji verimliliği yüksek mekanlar olmasıdır. Z kuşağı için yapılan ofis tasarımlarının makro özelliklerinin sonuncusu olarak bahsedilen çevre duyarlı ofis mekanları üretiminde; geri kazanılmış ahşap ürünlerin sıklıkla kullanılması, canlı bitkilerle açık havanın buluştuğu noktaların sıklığı, korunmuş ağaç kütüklerinden elde edilen masalar, yosun duvarlar ve kurulumu kolay prefabrik birimlerin seçilmesi gibi konulara dikkat edilmiştir (Sterkenberg, 2019). Sürdürülebilir ofis mekanları isteyen neslin teknolojiyle olan bağı düşünüldüğünde ek olarak dikkat edilmesi gereken özelliklerden biri de ofisin güncel dijital teknolojilere erişim kabiliyetidir. İlerleyen çağı yakalamak ve çalışma şartlarını iyileştirmek adına yeni çıkan teknolojiler takip edilmekte ve ofislerde dijital intiyaçlara erişim büyük ölçüde sağlanmaktadır. 
Genel olarak fiziksel (mobilya seçimleri, açık planlı ve bölmeli karma düzen, aydınlık mekanlar, uygun sıcaklık) ve sosyal (eğlenceli kullanım ortamları, toplanma yerleri, kullanıcının kendi tasarladığı mekanlar) özellikleriyle düşünülen ofisler yetişen her nesil için yeniden tasarlanmaktadır (Stallworth and Kleiner, 1996). Çalışma hayatının yeni katılımcıları olan Z kuşağı için düşünüldüğünde, tasarımcıların yukarıda anlatılan yaklaşımları ne derece isabetli bir karar olduğu tartışmalı bir konudur.

\section{GELECEĞiN ÇALIŞMA MEKANLARI}

Z kuşağının mekana olan bağlılığının yaşamakta olan diğer nesillere göre çok az seviyede olduğu görülmektedir. Dijital dünyaya doğan kuşak bireyleri için mekan kavramı da dijitalleşmiş ve sanal ortama giriş yapmıştır. Bilgi temelli çalışmaların yaygınlaşmasıyla ofis kavramı da çalışanların paylaşımda bulunduğu ve iş birliği yaptığı mekanlar olarak ayak uydurmayı denemiştir (Harris, 2015, s.429). Günümüzde genç neslin büyük çoğunluğu sanal dünyaların olduğu oyunlarla yetişmiş olup, gerçekte üretimi zor olan işleri sanal programlar yardımıyla geliştirmekte ve hatta çalışma arkadaşlarıyla iletişimi büyük oranda internet üzerinden kurmaktadır. Zaman kavramının ası önemi bu nesil tarafından kavranmış ve planlı, programlı bir hayat kuran neslin bireyleri gereksiz gördükleri sebeplerle harcanan zamana sürekli olarak tepki göstermişlerdir. Bu nedenle; tüm intiyaçlarını tek bir ekrandan giderebilen neslin çalışma amacıyla sabit bir işyerine gitmek için harcayacağı vakit yok denebilir.

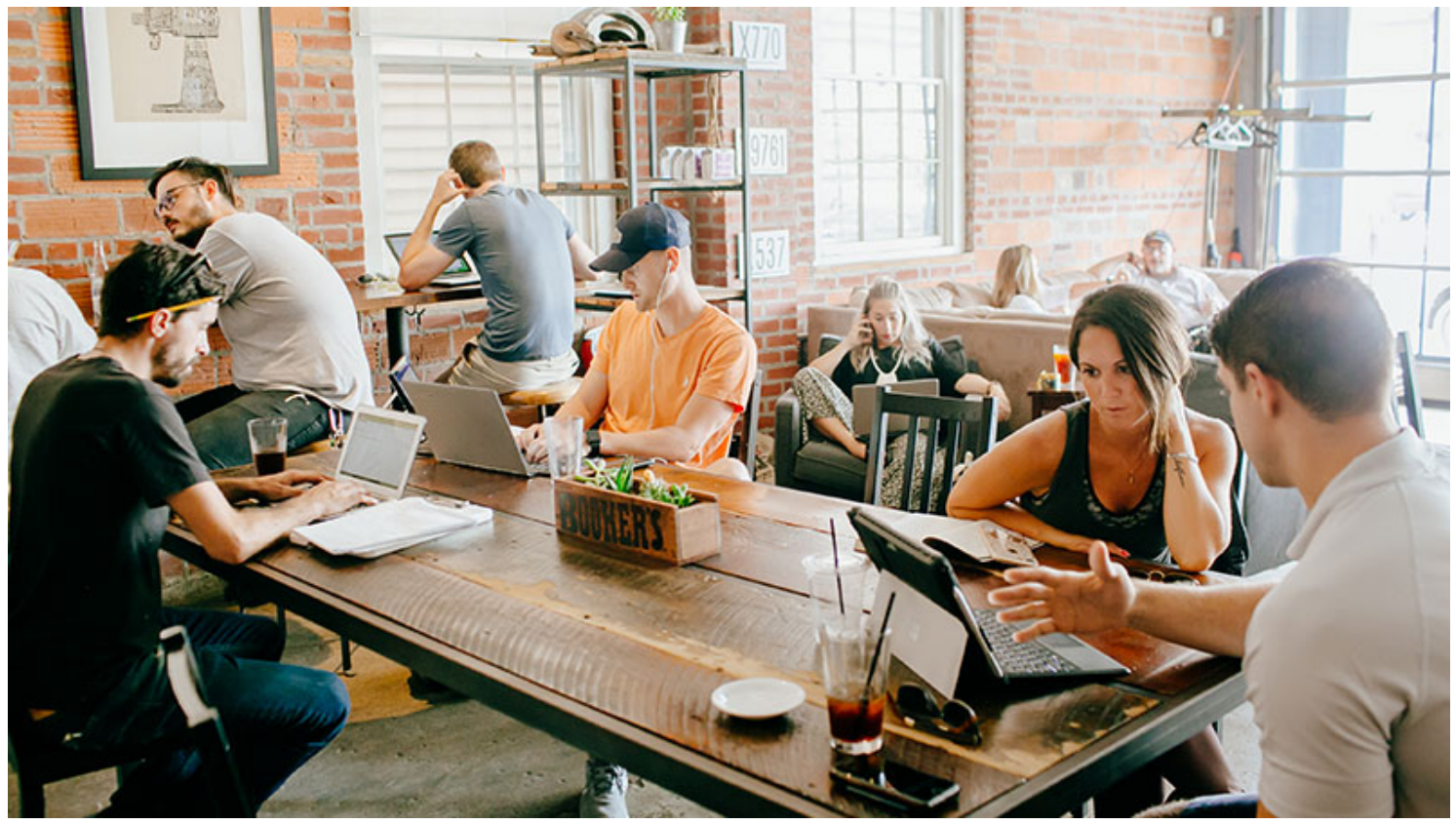

Şekil 4: Kafeleri çalışma mekanları haline getiren bireyler (URL 4)

Günümüzde Z kuşağı bireylerin büyük çoğunluğunun kafelerde çalıştığı izlenmektedir (Şekil 4). Farklı meslek gruplarından arkadaşlarıyla, istedikleri her an farklı mekanlarda buluşup yan yana kendi işleriyle ilgilenirken ara verdiklerinde sohbet edebiliyor olmayı istemeleri, Z kuşağının esnek çalışma saatlerindeki esneklik taleplerini ve işyeri mekanlarında bu nesle yönelik yapılan değişikliklerin sebeplerini açıklamaktadır. Firmalar tarafından iş yerlerinde bireyleri ortama adapte etmek için yapılan yeniden düzenlemeler, onları karakter özelliklerinin dışına itmeye zorlamaktır. Belirli saatlerde geldikleri adres, içinde her ne kadar farklı fonksiyonlarda mekanlar üretilmiş olsa da fikirsel olarak yapılmaya çalışılan bireylerin nesil özelliklerini değiştirmeye çalışmaktır. 
Z kuşağının çalışma hayatında prensipleri düşünüldüğünde, neslin bir mekandan çok mekansızlığa intiyacı olduğu anlaşılmaktadır. Bazı kaynaklarda Alfa kuşağı olarak adlandıılan 2010 sonrası doğan neslin Z kuşağından farklı olmayacağı yönündeki çıkarımlar, çalışma prensiplerinin de benzerlik göstereceği yönündedir (McCrindle, 2014, s.2020). Bu nedenle üretilen mekansızılk kavramı yeni dünyanın benimsemesi gereken bir kavram olarak sunulmaktadır.

\section{DEĞERLENDIRME VE SONUÇ}

Çalışma hayatında sahip olduğu yüzdelik dilim günden güne artan Z kuşağı bireyleri; sahip oldukları mobil çalışma alışkanlıkları ile bilgisayarlarını koydukları her mekanı, çalışma mekanına dönüştürmektedirler. İş ortamına dahil olmalarını sağlamak için sunulması gereken öncelikli özellik yüksek teknoloji intiyaçlarının karşılanması olarak belirlenebilmektedir. Dinamizmin sürekli olduğu jenerasyonun çalışma mekanında da fonksiyonu değişebilen esnek çözümlerin varlığı bireyler için önemlidir. Gerektiğinde toplantı salonuna dönüşebilen açık planlar ve ortak çalışma alanları kuşak için verimli bir tasarımdır. Özgürlük kavramına olan bağları düşünüldüğünde, daimi bir bağlılık aramayan açık planlı ofisler söz konusu kuşak için uygun sayılmaktadır. Türkiye'de örneklerinin İstanbul'da sıklıkla görüldüğü kolektif çalışma ofisleri yeni girişimci neslin ilgisini çoktan çektiği ve benzer işleyişle çalışan mekânız mekânlara ihtiyacın artmış olduğu gözlemlenmektedir.

Dönemin aşina olduğu teknoloji, hız, internet, değişkenlik, dinamizm... gibi kavramların $Z$ kuşağı bireylerinin hayatlarının her alanında var olan ve yönlendiren kavramlar olduğu görülmektedir. Bu sebeple iş hayatıyla gündelik hayatı birlikte yaşayan kuşak için iki mekanın intiyaçlarının sentezlenebildiği mekanlar ideal çözüm olacaktır. Söz konusu mekanın tasarımında dikkat edilmesi önemli hususlar; son teknolojiyle üretilmiş ürünlere erişimin olduğu donanımlı olması, değişime açık (esnek) mekanların varlığı, sosyalleşebilmeye imkan sağlaması ve önem verdikleri sağlıklı yaşam ihtiyacını karşılayabilmesi olarak listelenebilmektedir. Tüm bunlar düşünüldüğünde yeni nesil çalışma mekanlarının alışkın olunanlardan farklı olacağı öngörülmektedir.

Her yeni nesil, yeni ihtiyaçlar tanımlamış ve dönemin çözmesi için farklı problemler ortaya atmıştır. Jenerasyonların karakter özelliklerinin, çalışma hayatlarına dair kavramsal ve mekânsal beklentilerini etkilediği; $X, Y$ ve $Z$ kuşakları bağlamında incelenmiş ve bir kez daha bu çalışmada açıklanmıştır. Asıl olarak dijital bir dünyada yaşayan Z kuşağının çalışma hayatından mekânsal beklentilerini anlamak adına yapılan bu çalışma ile yetişen yeni neslin ihtiyaçları doğrultusunda kendi mekanlarını oluşturan ve çözümü kendi başlarına üreten becerikli bireyler oldukları açıklanmış ve üretilen mekansızıık kavramının yeni nesil için öneminin anlaşııması amaçlanmıştır.

\section{KAYNAKLAR}

Adıgüzel, Orhan, Zeynep Batur,ve Nisa Ek. 2014. "Kuşakların Değişen Yüzü Ve Y Kuşağı İle Ortaya Çıkan Yeni Çalışma Tarzı: Mobil Yakalılar." Süleyman Demirel Üniversitesi Sosyal Bilimler Enstitüsü Dergisi, no. 19: 165-182.

Akdemir, Ali, Gönül Konakay, Harun Demirkaya, Aral Noyan, Bülent Demir, Cengiz Ağ, Çağlar Pehlivan, vd. 2013. "Y Kuşağının Kariyer Algısı, Kariyer Değişimi Ve Liderlik Tarzı Beklentilerinin Araştırılması.” Ekonomi ve Yönetim Araştırmaları Dergisi 2 (2): 11-42. doi:10.4337/9781783476947. 
Arabacıoğlu, Cem, Burçin, ve Arabacıoğlu, Pınar, 2011. "Çağdaş Ofis Anlayışı ve 'Google'ın ‘Googleplex' Örneği’ 39-48.

Berkup, Sezin Baysal. 2014. "Working with Generations X and Y In Generation Z Period: Management of Different Generations in Business Life." Mediterranean Journal of Social Sciences 5 (19): 218-229. doi:10.5901/mjss.2014.v5n19p218.

Bouncken, Ricarda B., ve Andreas J. Reuschl. 2018. "Coworking-Spaces: How a Phenomenon of the Sharing Economy Builds a Novel Trend for the Workplace and for Entrepreneurship." Review of Managerial Science 12 (1). Springer Berlin Heidelberg: 317-334. doi:10.1007/s11846-016-0215-y.

Brennan, Aoife, Jasdeep S. Chugh, ve Theresa Kline. 2002. "Traditional versus Open Office Design: A Longitudinal Field Study." Environment and Behavior 34 (3): 279-299. doi:10.1177/0013916502034003001.

Çetin, Canan, ve Serol Karalar. 2016. "X , Y ve Z Kuşağı Öğrencilerin Çok Yönlü ve Sınırsız Kariyer Algıları Üzerine Bir Araştırma," 157-197.

Harris, Rob. 2015. "The Changing Nature of the Workplace and the Future of Office Space." Journal of Property Investment and Finance 33 (5): 424-435. doi:10.1108/JPIF-05-2015-0029.

Kırık, Ali Murat, Köyüstü, Sevda, 2016. The Investıgatıon Of Dıssertatıons On Z Generatıon With Content Analysıs Method, 0-2.

McCrindle, Mark. 2014. "The ABC of XYZ: Understanding the Global Generations." The $A B C$ of $X Y Z$ : Understanding the Global Generations, no. October: 264. http://mccrindle.com.au/resources/The-ABC-of-XYZ_Chapter-1.pdf.

Stallworth, Otto E., ve Brian H. Kleiner. 1996. "Recent Developments in Office Design." Facilities 14 (1-2): 34-42. doi:10.1108/02632779610108512.

Taş, Hacı Yunus, Mehmet Demirdöğmez ve Mahmut Küçükoğlu. 2017. "Geleceğimiz Olan Z Kuşağının Çalışma Hayatına Muhtemel Etkileri." OPUS Uluslararası Toplum Araştırmaları Dergisi 7 (13): 1031-1048. doi:10.26466/opus.370345.

Sterkenberg, Z. (2019) 'Office Futures: The Office Design Trends of 2020' https://www.ambius.com/blog/2020-office-design-trends/ erişim tarihi: 10.01.2020

[URL1] https://www.billi-uk.com/office-design-trends-over-the-years/

[URL2] https://www.helioshr.com/2019/03/open-office-concepts-are-they-in-or-out/

[URL3] Sterkenberg, Z. (2019) 'Office Futures: The Office Design Trends of 2020' https://www.ambius.com/blog/2020-office-design-trends/ erişim tarihi: 10.01.2020

[URL4] https://www.sewakantorcbd.com/blog/11-coffee-shop-untuk-kerja-yangnyaman-di-jakarta/ 